$10-2018$

\title{
Quality Function Deployment: More Than a Design Tool
}

Nadiye O. Erdil

University of New Haven, NErdil@newhaven.edu

Omid M.Arani

University of New Haven

Follow this and additional works at: https://digitalcommons.newhaven.edu/sgiengineering-facpubs

Part of the Engineering Education Commons, and the Operations Research, Systems Engineering and Industrial Engineering Commons

\section{Publisher Citation}

Nadiye Ozlem Erdil, Omid M. Arani, (2018). Quality function deployment: more than a design tool, International Journal of Quality and Service Sciences.

\section{Comments}

This is the authors' accepted version of the article published in International Journal of Quality and Service Sciences. The version of record can be found at http://dx.doi.org/10.1108/IJQSS-02-2018-0008 . 


\title{
Quality Function Deployment: More than a Design Tool
}

\author{
Nadiye Ozlem Erdil and Omid M. Arani \\ Department of Mechanical and Industrial Engineering \\ University of New Haven, \\ West Haven, Connecticut, USA
}

To cite this document:

Nadiye Ozlem Erdil, Omid M. Arani, (2018) "Quality function deployment: more than a design tool", International Journal of Quality and Service Sciences, https://doi.org/10.1108/IJQSS-022018-0008

\begin{abstract}
Purpose - This study investigates to what extent QFD can be used in quality improvement rather than design activities.

Design/methodology/approach - A framework was developed for implementation of QFD as a quality improvement tool. A case study approach is used to test this framework, and quality issues were analyzed using the framework in a ceramic tile manufacturing company.

Findings - The results showed considerable improvements in the critical quality characteristics identified and sales rates, demonstrating the potential of QFD to be used in assessing and prioritizing areas of improvement, and converting them into measurable process or product requirements.

Research limitations/implications - One case study was completed. More studies would be beneficial to support current findings.

Practical implications - This framework provides structured approach and guidelines for practitioners in adapting QFD for quality improvements in existing products or processes.

Originality/value - This study proposes a new framework to use QFD in quality improvement activities, expanding its application areas. Moreover, the results of the literature study performed provide a valuable collection of practical QFD implementation examples.

Keywords Quality function deployment (QFD), quality improvement, customer complaints, voice of customer (VOC), house of quality (HOQ)

Paper type Research paper

1. Introduction

Quality function deployment (QFD) is a methodology that helps translating customer needs into design requirements to ensure that the output, whether this is a product or process, meets these needs. Originated in the manufacturing industry, QFD also finds applications in service industries. QFD was developed in Japan in the late 1960s as a design process aid to incorporate customer voice into a product before it was manufactured. Its success came in the form of reduction in start up costs and development time and increased quality of a new product (Evans and Lindsay, 2015). Its applications are mostly found in design-related efforts, and many still limit QFD use to product design and development (Franceschini, 2002; Breyfogle III, 2003; Cheng 2003; NAE\&IM, 2005; Herzwurum \& Schockhert, 2006; Miguel 2007; Mitra, 2016). There are, however, exceptions to this; the American Society for Quality defines QFD as " $a$ structured process for planning the design of a new product or service or for redesigning an
\end{abstract}


existing one" (Tague, 2005); the International Organization for Standardization (ISO) describes QFD in the newly developed ISO 16355 standard as "a method to assure customer or stakeholder satisfaction and value with new and existing products by designing in, from different levels and different perspectives, the requirements that are most important to the customer or stakeholder" (ISO, 2015) .

This study investigates to what extent Quality Function Deployment can be applied in improvement efforts for existing products. To address this, first a literature review was performed which revealed an increase in the number of studies using QFD in improvement activities in the recent years. The majority of the QFD applications, however, are still in product design and development. Furthermore, when used in improvement activities, QFD is used as if gathering the voice of customer for a new design to generate specifications for re-design.

QFD is a powerful methodology for capturing and prioritizing customer needs and linking them to technical requirements. These features enable QFD for use in assessing and prioritizing areas of improvement, and converting them into measurable process or product requirements. In this study, a framework was developed for using QFD as an improvement tool. This framework was tested in a ceramic tile factory to demonstrate its application and examine QFD's effectiveness in this context.

The reminder of this paper is organized as follows: Section 2 presents an analysis of current QFD literature. Section 3 provides a summary of conventional QFD implementation, and then describes the proposed methodology. Section 4 demonstrates the implementation of the proposed approach through a case study and presents findings. Finally, Section 5 offers conclusions and future research directions.

\section{Literature Review}

QFD is a methodology that takes the voice of customer, i.e. customer expectations, and translates them into technical requirements to achieve the identified needs. Since its introduction, it has been used in various industries. A review of literature containing studies from 1992 to 2017 in over fifty-five journal titles shows a wide application scope. As seen in Table 1 QFD application areas extend from manufacturing to healthcare, and banking to transportation.

\section{INSERT Table 1. QFD Implementation Areas}

The studies resulted from this literature search were classified based on three criteria. The first classification grouped the studies according to their industry or setting. The second criteria separated studies based on their context. If QFD methodology was implemented in a manufacturing-related process, the entry was sorted under "Manufacturing" category. On the other hand, if QFD was applied to a service-related process, the entry was listed under "Service" category. The final classification was based on whether QFD was used in design and development or improvement activities. For example, Sharma and Rawani (2007) provides a case study involving syringe and needle manufacturing where the customer base was in healthcare, thus this study was classified under healthcare industry/setting, and manufacturing context. Similarly, Ho et.al (2011) applied their QFD model to an automobile manufacturing company with a focus on their strategic sourcing. Therefore, this study was listed under automotive industry and service context. Both studies were conducted in design and development phase.

A closer look at Table 1 shows that most of the QFD implementation still takes place in the design and development stage (Figure 1). One of the reasons for this lies in the way QFD was 
introduced to the Western culture (Govers, 2001). QFD was introduced as a design tool in Japan, and the continuous improvement (kaizen) philosophy embedded in Japanese culture had an influence on its deployment. This philosophy was not inherited during the adoption of QFD in the Western culture; and this limited QFD to be a "design tool" (Akao \& Mazur, 2003).

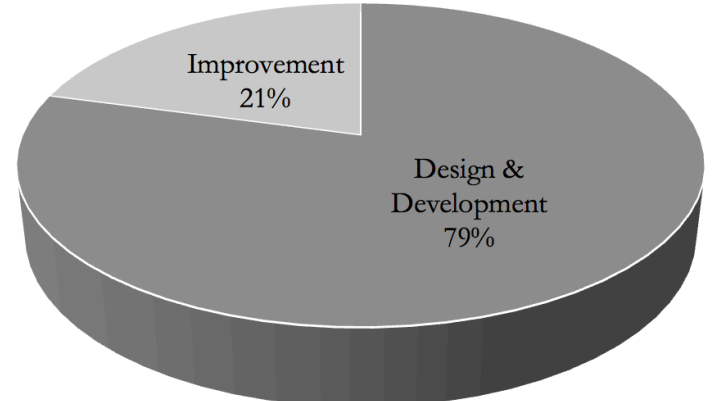

Figure 1. QFD Applications - Design \& Development vs. Improvement

When the context is considered, the implementation of QFD portrays a slightly different picture (Figure 2) in manufacturing and service industries. While QFD is used mainly in design and development in manufacturing, the gap between different applications of QFD in service is not as significant. Furthermore, more applications of QFD are observed in service industry. This is attributable to the increasing rate of adoption of QFD in non-manufacturing related areas in the recent years and more publications on QFD in service industry because it is fairly a new approach in this setting compared to manufacturing industry.

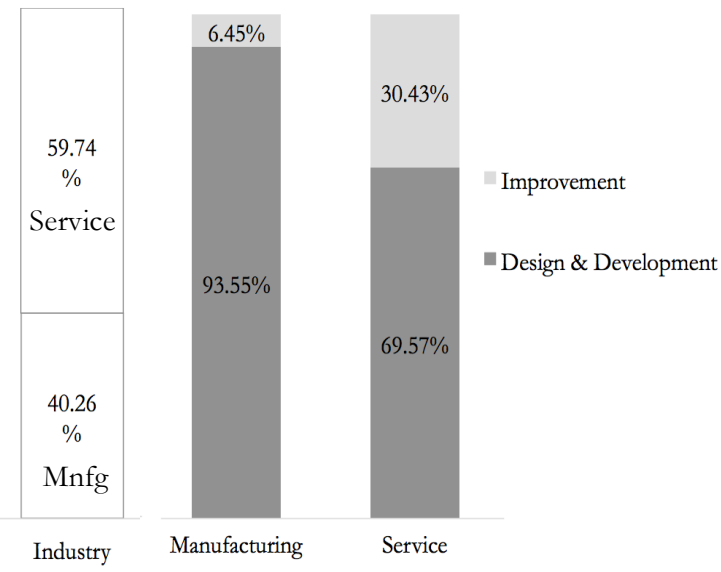

Figure 2. QFD Applications - Manufacturing vs. Service Industries

Figure 3 displays QFD studies through time in which a few sporadic applications of QFD in improvement activities in the recent years is observed. Most of these studies were from service industry, and in these studies traditional QFD implementation was followed.

Mazur (2014) argues that QFD is a method that can be applied to new and existing products or services, and that it is an effective method in generating customer satisfaction and value. Nevertheless, in addition to the findings based on the analysis of studies listed in Table 1, the literature, furthermore, suggests that QFD is considered a method typically limited to product 
design and development. In a study conducted by Miguel (2003), the top 500 companies in Brazil were surveyed about their use of QFD. One of the main reasons for using QFD was identified as better-managed product development process. Increasing customer satisfaction and improving communication in cross-functional teams were among the other reasons selected. In a follow up study, Miguel (2007) asked four large companies, US and non-US based, (two automotive, one machinery, and one plastics) to classify their QFD projects in one of the following categories: new product platform, modification of an existing product platform, and little modification in existing products. The results showed that, except machinery, all companies employed QFD to develop a new product platform.

In another survey study investigating the adoption of continuous improvement strategies in Australian manufacturing firms, Terziovski \& Sohal (2000) found that only $14.1 \%$ of the 385 organizations utilized QFD in their improvement practices. Besides, it was not clear in the article if QFD was used for existing products or services.

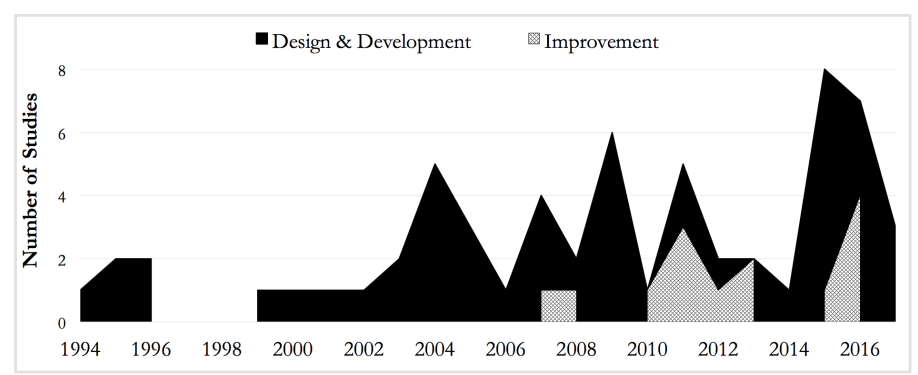

Figure 3. QFD Applications through time

He et al. (2002) studied the integration of several quality tools, including quality function deployment, failure mode and effect analysis (FMEA), design of experiments (DOE) and statistical process control (SPC), and proposed a quality integration model which provided a roadmap for the use of aforementioned tools in design and manufacturing stages. The design stage referred to activities in efforts to improve the quality of product in the design phase, and QFD, FMEA, DOE and SPC were all placed in this stage. The manufacturing stage represented activities that are employed to continuously improve product quality during the manufacturing process. The tools included in this section were SPC, DOE and some other analytical tools, limiting QFD to design only.

ISO 16355 is an eight part standard on QFD, of which part 1 was published in 2015, parts 2, 4,5 , and 8 were published in 2017, and the remaining parts are under development (ISO, 2015; ISO, 2017a, ISO2017b, ISO 2017c; ISO, 2017d). ISO 16355 describes key QFD concepts and provides a collection of methods and tools used in QFD implementation. Part 1 describes the QFD process, its purpose, users and tools. Generational improvements to existing products are listed among the types of QFD projects in Part 1. Yet, the title of the standard is "Application of statistical and related methods to new technology and product development process", which clearly inherits the traditional QFD approach focusing on only new product and design. Since the complete standard is not fully published, it is not considered further within this study.

On the other hand, there are a few examples in the literature that promote QFD use in improvement activities, but no extensive research exist that focus on establishing QFD as a process and quality improvement tool. Zubek and Nibley (1994) used QFD to align management 
requirements to critical business processes. The management requirements included reducing costs, improving quality, standardizing engineering functions, and increase throughput which were mapped to configuration drawing, product development structure, materials standards and design standards. Kaneko (2000) presented a hypothetical proposal for using QFD to upgrade an existing car and suggested using market verification as a starting point. Kapucuglu-Ikiz and Ozdagoglu (2008) applied Blitz QFD for process improvement through operational requirement analysis in a shipping sector to determine design issues within the operation process. Blitz QFD is a method created to analyze business operations, and is a tailored traditional QFD replacing matrices with many small focused tools. Cudney et al. (2012) used to generate recommendations for a professional society to improve their customer satisfaction and increase their member-base. But, while the focus in this application was on an existing service, QFD was implemented in an approach similar to its use in design and development, and a process re-design was done.

QFD is typically used as a design tool. Yet, it could be used any time when customer needs have to be identified to determine technical requirements for the purposes of determining priorities and setting targets. QFD can be a powerful aid in improvement activities especially when quality is of concern. Lack of framework and guidelines in implementing QFD to enhance the quality of an existing product or process, however, contributes to its low utilization in this context. An approach to use QFD as a quality improvement tool is presented in the following sections.

\section{Methodology}

\subsection{QFD Process}

QFD implementation involves a set of matrices. In full implementation, there are four matrices. The first one is called the House of Quality (HOQ). The term House of Quality is often used to refer to QFD, but this initial matrix itself does not constitute the full implementation. HOQ takes customer requirements and translates them into technical (design) requirements. The second matrix turns technical requirements into part specifications, which are then expressed in terms of process requirements in the third matrix. Finally, quality specifications are defined in the last matrix (Figure 4).

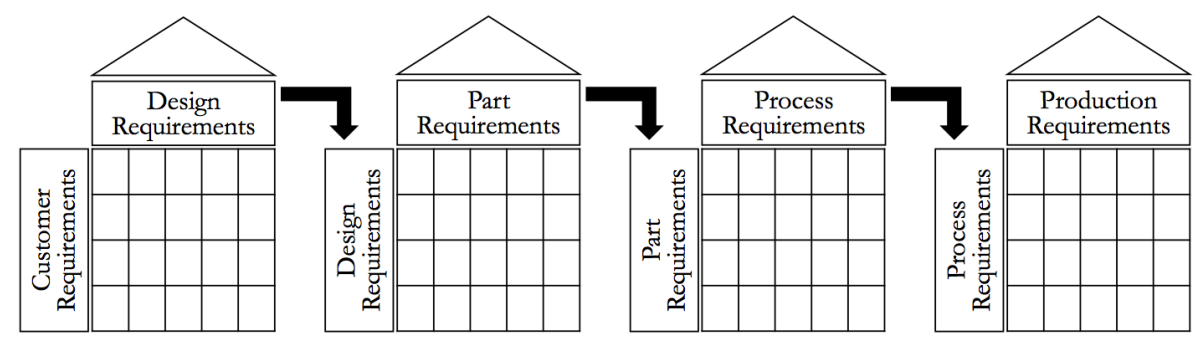

Figure 4. Phases of QFD Process

HOQ is a critical element in the QFD process as it captures the voice of the customer as well as it constructs a pathway for the direction of further efforts (Herzwurum \& Schockhert, 2006). It is the most commonly utilized QFD component. The steps to develop HOQ are described in the following text. Figure 5 shows the elements of HOQ. Each element is numbered based on the sequence it is completed when generating HOQ.

Step 1) Identify customer needs and determine their degrees of importance

Customer needs (requirements) are usually gathered from surveys, interviews, focus groups, and other similar methods. It is important to also gather the degree of importance of each need when 
identifying customer needs. The customer needs can be defined in primary, secondary, and tertiary levels, with each level providing more details of the expressed need. Customer needs, which are sometimes called "whats", are turned into technical requirements, called "hows", in the next step.

\section{Step 2) Identify technical requirements and determine interrelationships}

After listing the customer needs and their degrees of importance, the technical requirements have to be established. Customer needs are expressed in the language of the customer such as a computer user stating "I would like to see the colors vividly on my screen". Technical requirements are translation of these needs into design requirements expressed in measurable attributes. In the screen example the attributes may be color support, aspect ratio, pixel pitch, etc. Each technical requirement can fulfill one or more customer needs. The team developing the QFD identifies the technical requirements.

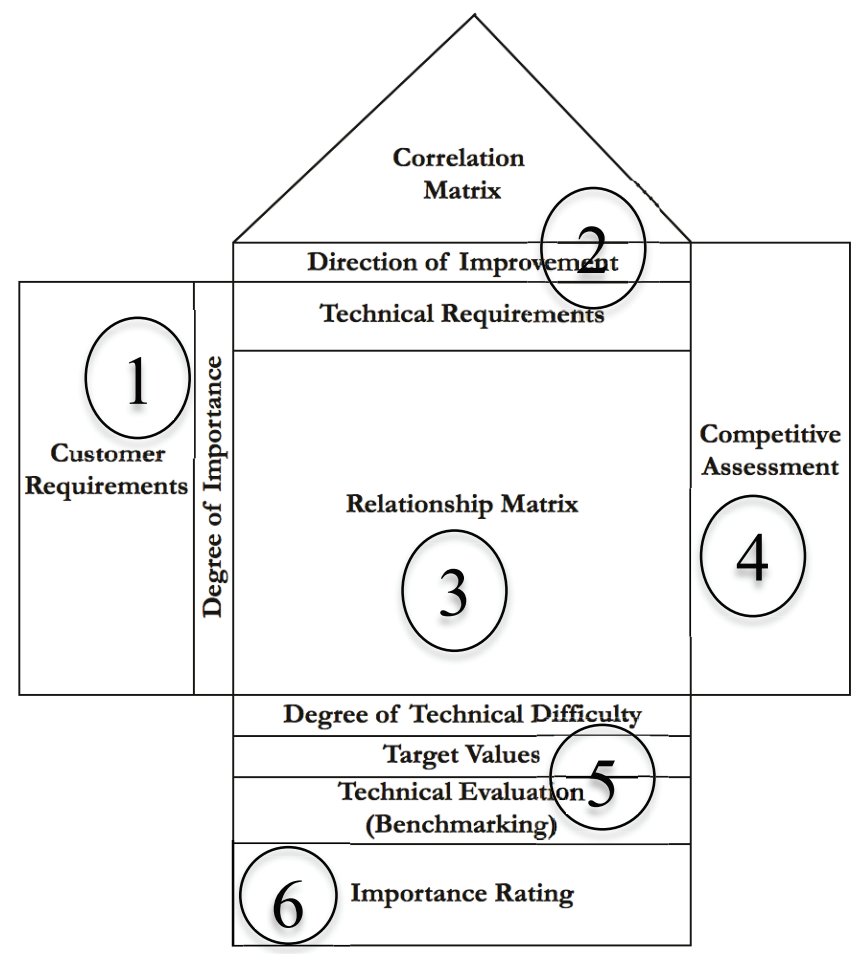

Figure 5. House of Quality

The roof of HOQ is used to show the correlation between the technical requirements. It is important to identify which technical requirements support or work against each other. Table 2 shows the symbols and the corresponding correlation used to portray the correlations in HOQ.

\section{INSERT Table 2. Symbols used in the roof of House of Quality}

Also included in this step is the identification of the direction of improvement (maximize, minimize or achieve a target value) for the technical requirements. This information is stored in a row between the roof and the row listing technical requirements. 
Step 3) Determine relationships between customer needs and technical requirements

This is the center of HOQ. The customer needs that are listed on the left column are connected to the technical requirements listed across the top by filling in the section called the relationship matrix in Figure 5. Table 3 shows the symbols, and the corresponding relations as they are used to identify the relationships between the customer and technical requirements. There needs to be at least one technical requirement that has a strong relationship with one of the customer requirements. Its lack may indicate that a particular customer need may not be substantially addressed. Similarly, if a technical requirement is not strongly connected to any of the customer needs, this requirement should not be included in the QFD analysis.

\section{INSERT Table 3. Symbols used in the relationship matrix}

Step 4) Perform competitive analysis

Competitive analysis evaluates the company in study against its competitors. In this step, competitors' products or services are reviewed in satisfying the customers' needs shown in the left most column of the matrix. 1 to 5 scale, five being the best, can be used in evaluating each competitor product.

Step 5) Develop target values for technical requirements and determine technical difficulties Using the results of the competitive analysis and the degrees of importance for customer needs, target values are selected for the technical requirements. The requirements that correspond to the needs for which the competitors are doing better and for the ones that have higher degree of importance get more emphasis. Then, the technical difficulties are identified based on how difficult it is to achieve the target values selected for each technical requirement. The rankings are done typically using a five-point scale with 1 being the easiest and 5 the most difficult.

In some QFD implementations, this step also includes competitor evaluation in terms of technical requirements, and the results are recorded in a row included in the basement of the matrix before the importance ratings.

Step 6) Calculate importance ratings

This section completes the basement of the house where the importance ratings are recorded. The importance ratings are calculated to identify which technical requirements will get the most attention in the following steps of the QFD process. The importance ratings are the relative weights of each technical requirement based on the weight of each item in terms of satisfying the customer needs. The weight of each technical requirement is calculated using the following expression

$$
W_{j}=\sum_{i=1}^{n} d_{i} r_{i j}
$$

where $W_{j}$ is the weight of $j^{\text {th }}$ technical requirement, $d_{i}$ is the degree of importance of $i^{\text {th }}$ customer requirement; and $r_{i j}$ is the relationship coefficient between the $i^{\text {th }}$ customer requirement and the $j^{\text {th }}$ technical requirement, which can be extracted from the "relationship matrix" in the HOQ chart. The relative weights are then determined using the following equation

$$
Z_{j}=W_{j} / \sum_{k=1}^{m} W_{k}
$$


where $Z_{j}$ is the relative weight (importance rating) of the $j^{\text {th }}$ technical requirement. Technical requirements with higher importance ratings and poor in performance compared to competitor products are moved to the second phase where another matrix is generated to identify the part characteristics using the same process described above. The technical requirements in this case are entered in the left column of the new matrix. This process continues until the last matrix in the QFD implementation is completed.

\subsection{QFD Implementation - Traditional Approach}

QFD is most commonly applied in the early phases of the design to translate the voice of customer into design requirements. Therefore, HOQ, which was described in the previous section, is the most utilized component of QFD. The complete QFD process follows a waterfall diagram as shown in Figure 6. Each matrix in Figure 4 helps develop input for the next step in sequence. HOQ generates design requirements. The design requirements are translated into part characteristics, which are then used to determine manufacturing processes best suitable for producing the new product. In the last stage, production requirements, i.e. quality control plans to ensure that the product meets manufacturing requirements, are identified. Plans include statistical process control, preventative maintenance, operator instructions, and so on. The adoption of QFD in service industries involves interpreting these steps in terms of service elements. Apart from that, the process follows the same waterfall flow. QFD is an extremely useful methodology if done correctly. Cross-functional teams is one of the key elements. Furthermore, establishing clear objectives and scope of using QFD, obtaining management commitment, and gathering quality data are other factors for effective implementation of QFD.

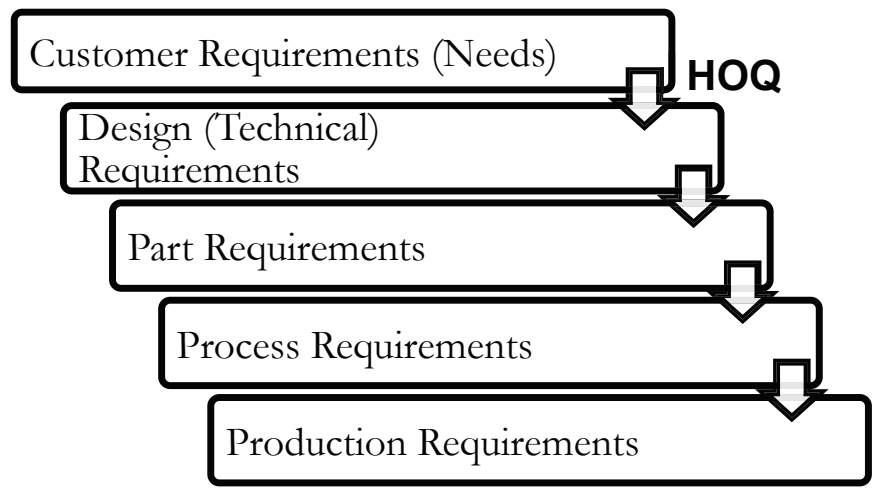

Figure 6. Process flow in traditional QFD Implementation

\subsection{Method \& Design: QFD as an Improvement Tool}

The traditional approach restricts QFD application to design and development. QFD, nonetheless, has potential to be used in improving existing products or services. Figure 7 shows our proposed approach in which QFD is used to enhance the quality of or to reduce quality problems in existing products. In the former, the results of QFD lead to preventive actions while the latter generates corrective actions. In this proposed approach HOQ would be the primarily utilized component as in the traditional QFD implementation. But in this HOQ customer requirements represent areas of improvements. These areas are linked to technical requirements that later guide the development of actions. Depending on the complexity of the technical characteristics, subsequent matrices can be developed as in the traditional approach to define a 
particular improvement activity.

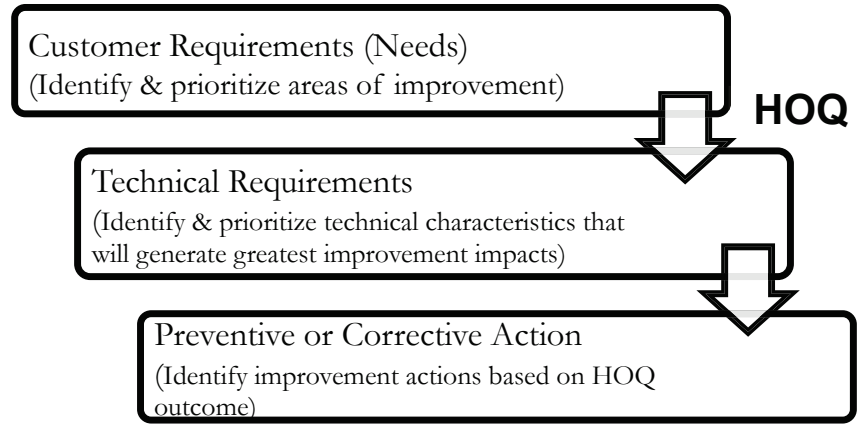

Figure 7. Process flow for QFD as an improvement tool

Integrating customer complaints in the QFD model helps the organization to investigate the root cause of customer dissatisfaction (Warwick Manufacturing Group, 2007). In the proposed framework, the customer complaint history is used as a main source for customer need identification in addition to the traditional QFD data collection tools. The types and frequency of complaints provide data on customer needs and their degrees of importance as shown in Figure 8 .

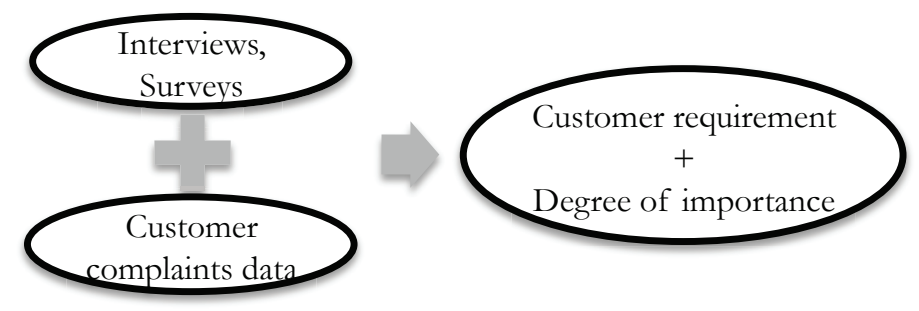

Figure 8. Gathering voice of customer

The identification of technical requirements is then done similar to the traditional approach. The third stage is to translate technical requirements into actions that will generate improvement plans. Preventive or corrective actions are evaluated in order to select feasible, effective actions that cover one or more most important customer requirements.

QFD is promoted as a tool focusing on maximizing positive quality by incorporating customer needs into product design from the conceptual phase in contrast to traditional quality systems that aim to minimize negative quality from the product (Mazur, 1993). Nevertheless, quality problems do occur after the product or process is brought to life. This suggested approach helps to expand the role of QFD, and places it in the quality improvement models. One of the most important goals of the traditional QFD is to get the design correct the first time by incorporating customer voice from the start. QFD has been successful in achieving this goal which is the reason it is widely used despite the great efforts needed for its implementation. The use of QFD as an improvement tool can provide similar benefits. The QFD will help the improvement team to identify issues that need the most attention as well as to determine the technical aspects of the product or process that will produce the greatest improvements.

\section{Case Study 4.1 Methodology}


A case study was used to apply the proposed QFD framework to demonstrate its implementation and to assess its effectiveness as an improvement tool as described above. The study was conducted in a ceramic tile-manufacturing factory, and the issues with the quality of tiles were analyzed. The company was receiving large number of customer complaints. Furthermore, the marketing reports were reflecting flat annual sales despite increasing sales forecast. To eliminate the quality issues, the proposed QFD implementation explained in section 3.2 was followed and the technical requirements were identified and linked to corrective actions.

Customer requirements were extracted from two sources, customer complaint history and interviews. Interviews were conducted with wholesalers that had close relations with customers and knew about their needs. The results of these interviews were treated as voice of customer who had not filed a complaint but in fact had some dissatisfaction about the product. These results were combined with the reported customer complaints to generate input to QFD.

In this proposed approach, it is possible to describe customer requirements in technical terms rather than in the language of the customer, because these requirements are described by the QFD team, and their importance or their lack of are determined by customer complaint history data and the interviews. Furthermore, since the product or the process already exists, translating customer verbatim into technical requirements is straightforward.

To complete HOQ, the process detailed in section 3.1 was followed. First, the information gathered from customer complaints data was transferred to the left hand column of the HOQ matrix. Technical requirements related to each customer requirement (customer complaint type in this case) were identified by the QFD team. The relationships between the technical requirements and the customer requirements, information needed to complete steps 2 and 3 , were generated during the QFD team meetings. Step 4, competitive analysis was performed with two competitor products which were tested in the laboratory against each requirement. Finally, the bottom of HOQ was completed. The estimates for the competitors' products were obtained from the laboratory tests. The degree of difficulty and the relationship between the technical requirements were established based on expert knowledge, consultants' recommendations, and available information about competitors' experiences.

\subsection{Application}

\section{Customer Requirements}

First, the QFD implementation team generated a list of issues based on expert knowledge from production, service and marketing. These issues, called complaint types, were classified into two categories: product and service (Table 4). The product issues were related to the appearance of the tiles and the tile structure and were identified as color variation, surface finish, packaging, straightness, dimension variation and resistance. The service items were mainly sales related and were defined as price, after-service and item availability.

\section{INSERT Table 4. List of issues generated by the QFD team}

\section{Interviews}

80 wholesalers were surveyed to gather information on the types of complaints that were identified by the QFD team. The wholesalers were asked to rate how frequently each complaint type occurred based on their experiences with the customers. The rating was on a three-point scale, with 3 being frequently, 2 being occasionally, and 1 being rarely. The survey results and the calculated scores for each category are shown in Table 5. The frequency (F) is the weighted 
mean, and is calculated using Equation 3 where $R$ represents the quantitative value of the rank assigned and $N$ represents the frequency of $i^{\text {th }}$ rank.

$$
F=\frac{\sum_{i=0}^{2} R_{i} N_{i}}{\sum_{i=0}^{2} N_{i}}
$$

\section{INSERT Table 5. Wholesaler evaluation of complaints}

\section{Customer Complaint History}

The complaints that were filed in the previous year were analyzed by first identifying the types of complaints, and then the number of complaints for each type. There were total 54 complaints. About sixty percent of these cases had a nature of complaint that matched with a type of complaint identified by the QFD team. The remaining were single cases related to other issues, which were grouped under Other and were excluded from the rest of the QFD analysis. Table 6 shows the frequency summaries.

\section{INSERT Table 6. Customer complaints prior to QFD implementation}

The degree of importance for each complaint category was calculated by combining the data from the two sources described above. The customer complaints data had a weight of 5 as it provided a direct input from the customer while the data from the wholesaler interviews were assigned a weight of 2 . Table 7 shows the list of customer requirements along with their degrees of importance. The cumulative rank is calculated by factoring in the weights of each input data, and the scaled rating is a placement of the cumulative rank on a 1 to 9 scale.

\section{INSERT Table 7. Customer requirements and their degrees of importance}

\section{Completion of QFD}

The information in Table 7 generated the input for the QFD, and was entered into the left hand column of the HOQ matrix. The rest of HOQ was completed as detailed in Section 4.1 The final HOQ chart is shown in Figure 9. One of the customer requirements, price, did not show a strong relationship with any of the technical requirements, however the QFD team decided that the existing two relationships, medium and weak, were sufficient to address this item. Similarly, the technical requirement firing domain was not strongly connected to any of the identified needs, but the team chose to include it in the analysis due to its medium and weak relationships with multiple customer requirements. 


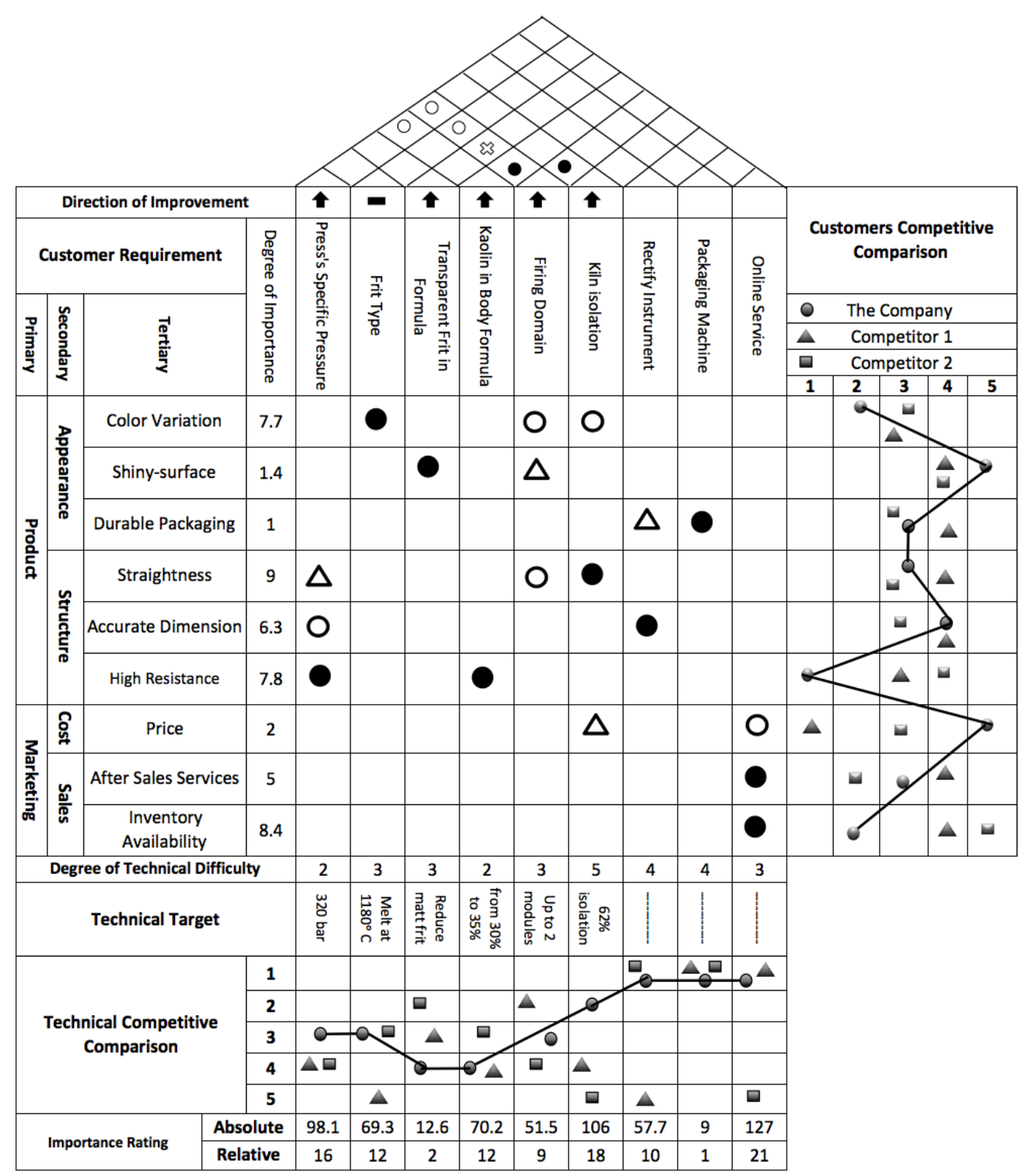

Figure 9. House of Quality linking customer complaints to technical requirements

\subsection{Findings and Discussions}

Online service, kiln isolation, and press pressure were the technical requirements with the highest relative importance ratings in the completed HOQ. This meant focusing on these requirements would generate greater impacts in terms of addressing the items the customers complained about the most. The actions were identified as providing online services which the company did not have at the time, improving kiln isolation and increasing the press pressure. Kiln isolation improves the composition of the kiln atmosphere which in turn would lead to reduction in color variation. Kiln isolation may also improve deviation observed from the center of the tile. This deviation causes issues with tile straightness. Increased press pressure increases bulk density of tile body, which generates stronger tiles and tiles that are more heat-resistant. 
These changes also help improving non-linearity and deviation issues. Online services including sales, warranty claims, and inventory inquires target to improve tracking of purchase transactions hence to improve after sales related issues.

The implementation took two months. After a six-month control period internal and external analyses were performed to measure the effectiveness of the actions taken. Figure 10 shows the before and after comparison of the company's product performance on each customer complaint type. The after-implementation ratings were obtained by performing competitive comparison as explained in the competitive comparison section below, and the before-implementation ratings were acquired from the product evaluation in the original HOQ.

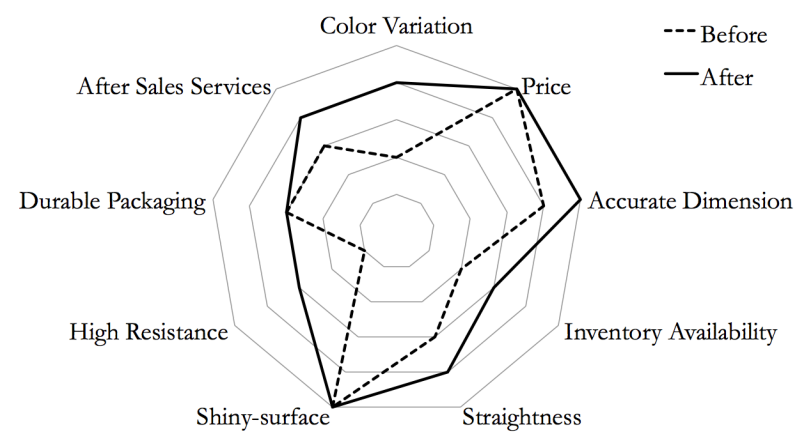

Figure 10. Tile performances - Before and After Comparison

In HOQ analysis, after sales services and inventory availability were strongly related to online services. As Figure 10 shows, these two issues were reduced after the introduction of online services. Similarly, straightness, which was strongly linked to kiln isolation, and highresistance, which was strongly linked to the press pressure, were improved. The two customer requirements, color variation and accurate dimension, were also improved in the process. The reason was the moderate relationship between these customer requirements and the two technical requirements selected for improvement actions.

The sales data also showed improvements. Figure 11 shows the tiles sold in meter squares for the last six years. Following the QFD implementation, which occurred at the end of year 4 and in early year 5, the company recorded increasing sales trend. While it is possible that other factors might have had an impact on sales, since there were no significant changes in the market during this period, the improvement recorded was largely attributed to the project that utilized QFD.

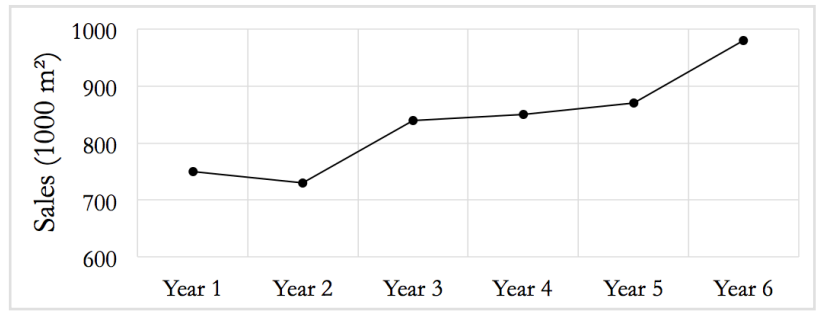

Figure 11. Total meter square tiles sales data 


\section{Competitive Comparison}

The company and competitors' products were tested against the customer requirements one more time after the implementation of the improvement actions. The data for the product related items were obtained from the laboratory tests, and the service-related items were based on available market information. The right side of HOQ with before and after data in Figure 12 shows that the improvements had external impacts too.

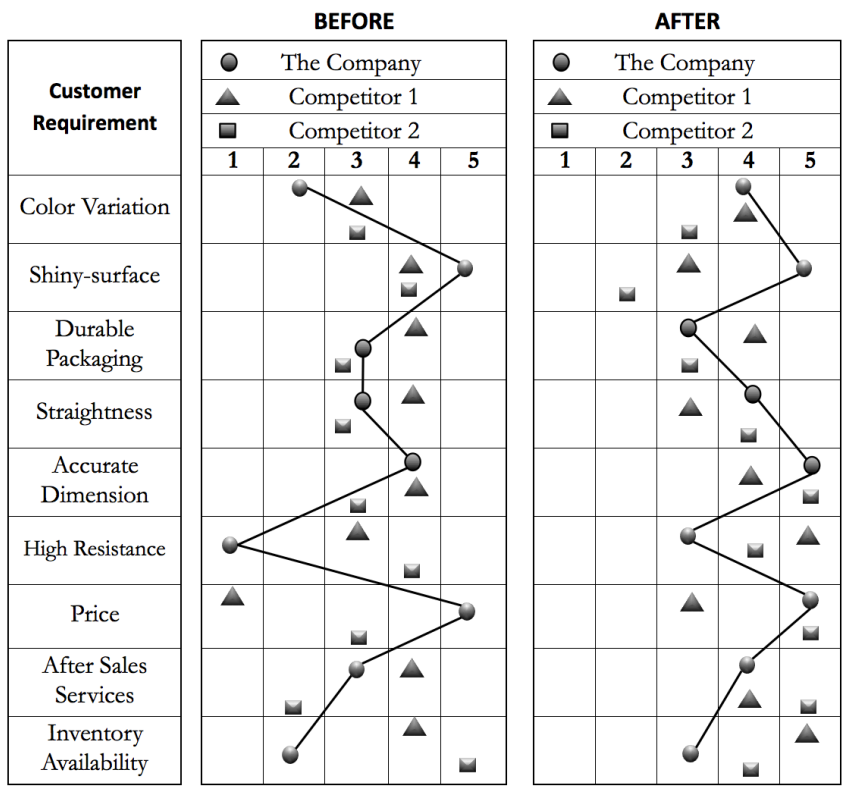

Figure 12. Before and after competitive assessment

\section{Implications}

In the case study described above, the customer requirements were obtained through the interviews and filed customer complains. These requirements constituted input to QFD to generate technical requirements, which were then used to guide improvement actions to address customer issues and to improve product quality. The results were significant, which support the purpose of this study that QFD implementation can be expanded, and that QFD can be used as an improvement tool for an existing product, service or process. While this study presents an example from manufacturing, the proposed framework is not specific to an industry, but is intended to be applicable to the wide spectrum of projects where QFD can be applied. Similar to studies in the literature this study uses HOQ as an essential tool. HOQ provides a structured approach in prioritizing customer needs, and connecting them to technical requirements. In the proposed framework, this connection helps to generate focused improvement efforts which can be applied in all types of organizations and industries.

Furthermore, the framework presented can be tailored based on available data or the need. This study uses interviews and customer complaints as the main source for voice of customer. Information from tools that provide customer or process voice such as warranty returns, gemba visits, kano model, and value stream maps, can be integrated into the framework. Each source would receive a weight assignment and would be included in the analysis to generate an input to HOQ. 


\section{Conclusion}

In this paper, a framework was proposed to adopt QFD as a quality improvement tool. An extensive literature search showed that QFD implementation still largely takes place in design and development, especially in manufacturing industry. Only a small fraction uses QFD to improve the quality of an existing product, and in those cases traditional QFD implementation is followed. The proposed approach utilizes QFD methodology to identify and prioritize areas of improvement. In doing so, customer complaints history is used in addition to the traditional voice of customer tools such as surveys, focus groups and interviews. HOQ links areas of improvements to technical requirements. Revealing these connections helps the improvement team to identify and prioritize technical characteristics that will generate the greatest improvement impacts. The results of QFD lead to preventive actions or corrective actions depending on whether the improvement efforts were to address quality issues or to enhance a product or process. The proposed framework was tested with a case study and the results showed considerable improvements in areas with customer complaints and sales volumes, demonstrating the potential of QFD in assessing and prioritizing areas of improvement, and converting them into measurable process or product requirements. Although its implementation would require more effort compared to other improvement tools, QFD shows a bigger picture of the problem while providing more targeted information to achieve greater impacts.

This study proposed a framework which expands QFD application areas. This framework provides guidance for practitioners in adapting QFD for quality improvements in existing products or processes. Furthermore, the literature review performed to identify the research gap provide a valuable collection of practical QFD implementation examples. The case study presented focuses on the application of QFD in manufacturing. Future work includes testing the framework with more case studies from manufacturing and service industries to support current findings and to extend application areas to service industry. For researchers, the framework provides a template for placement of QFD in improvement models. This template can be tailored to support the popular quality and process improvement methodologies such as Six Sigma, Lean, and PDCA; which will help QFD to be established as an important quality and process improvement tool.

\section{References}

Ahmed, S.M., Sang, L.P. and Torbica, Z. M. (2003), "Use of quality function deployment in civil engineering capital project planning”, Journal Of Construction Engineering And Management, Vol. 129 No. 4, pp. 358-369.

Akao Y. and Mazur G. (2003), "The leading edge in QFD: past, present, and future", International Journal of Quality and reliability Management, Vol. 20 No. 1, pp. 20-35.

Al-Mashari, M., Zairi, M. and Ginn, D. (2005), "Key enablers for the effective implementation of qfd: a critical analysis", Industrial Management \& Data Systems, Vol. 105 No. 9, pp. 1245-1260.

Alsyouf, I., Al-Aomar R., Al-Hamed, H., and Qui, X. (2011), "A framework for assessing the cost effectiveness of lean tools", European Journal of Industrial Engineering, Vol. 5 No. 2, pp. 170-197.

Andronikidis, A., Georgiou, A.C., Gotzamani, K. and Kamvysi, K. (2009), "The application of quality function deployment in service quality management", The TQM Journal, Vol. 21 No. 4, pp. 319-333.

Armacost, R.L., Componation, P.J., Mullens, M.A. and Swart., W.W. (1994), "An AHP framework for prioritizing customer requirements in QFD”, IIE Transactions, Vol. 26 No. 4, pp. 72-79.

Azadi, M. and Farzipoor Saen, R. (2013), “A combination of QFD and imprecise DEA with enhanced Russell graph measure: A case study in healthcare”, Socio-Economic Planning Sciences, Vol. 47 No. 4, pp. 281-291. 
Balthazard, P.A. and Gargeya, V.B. (1995), "Reinforcing QFD with group support systems Computer-supported collaboration for quality in design", International Journal of Quality \& Reliability Management, Vol. 12 No. 6, pp. 43-62.

Batson, R.G. and Moynihan, G.P. (2004), "Using QFD to plan for quality of knowledge work", IIE Annual Conference Proceedings, pp.1-7, Institute of Industrial and Systems Engineers.

Benitez, Y., Forrester, L., Hurst, C. and Turpin, D. (2007), "Hospital reduces medication errors using DMAIC and QFD”, Quality Progress, Vol. 40 No. 1, pp. 38-45.

Bergquist, K. and Abeysekera, J. (1996), "Quality Function Deployment (QFD) - A means for developing usable products", International Journal of Industrial Ergonomics, Vol. 18 No. 4, pp. 269-275.

Bhattacharyya, M. and Chaudhuri, A. (2009), "A combined QFD and Fuzzy integer programming framework to determine attribute levels for conjoint study", Product Research: The Art and Science Behind Successful Product Launches, Vol. 47 No. 23, pp. 245-258.

Breyfogle, I. and Forrext, W. (2003), Implementing Six Sigma: Smarter Solutions Using Statistical Methods, $6^{\text {th }}$ ed., Wiley \& Sons, Inc., Hoboken, New Jersey.

Buttigieg, S.C., Dey, P.K. and Cassar, M.R. (2016), "Combined Quality Function Deployment and the Logical Framework approach to improve quality of emergency care in Malta", International Journal of Health Care Quality Assurance, Vol. 29 No. 2, available at:https://doi.org/10.1108/IJHCQA-04-2014-0040.

Camgöz-Akdağ, H., İmer, H.P. and Ergin, K.N. (2016), "Internal customer satisfaction improvement with QFD technique”, Business Process Management Journal, Vol. 22 No. 5, pp. 957-968.

Chadawada, R., Sarfaraz, A., Jenab, K. and Pourmohammadi, H. (2015), "Integration of AHP-QFD for selecting facility location", Benchmarking: An International Journal, Vol. 22 No. 3, pp. 411-425.

Chan, C.Y.P. and Mazur, G.H. (2010), "QFD-based curriculum development model for industrial training", 22nd International Symposium on QFD, Portland, OR.

Chen, C. and Wu, H. (2007), "Combining QFD and process management techniques in Phase-in Nanotechnology an empirical study of the semiconductor Industry", Industrial Engineering Research Conference, pp. 1004-1010.

Chen, L.H. and Ko, W.C. (2009), "Fuzzy linear programming models for new product design using QFD with FMEA", Applied Mathematical Modeling, Elsevier Inc., Vol. 33 No. 2, pp. 633-647.

Chen, Y.Z. and Ngai, E.W.T. (2008), “A fuzzy QFD program modeling approach using the method of imprecision”, International Journal of Production Research, Vol. 46 No. 24, pp. 6823-6840.

Cheng, L.C. (2003), "QFD in product development: methodological characteristics and a guide for intervention", International Journal of Quality \& Reliability Management, Vol. 20 No. 1, pp. 107-122.

Cherif, M.S., Chabchoub, H. and Aouni, B. (2009), "Integrating customer's preferences in the QFD planning process using a combined benchmarking and imprecise goal programming model", International Transactions in Operational Research, Vol. 17 No. 1, pp. 85-102.

Cordeiro, E.C., Barbosa, G.F. and Trabasso, L.G. (2016), "A customized QFD (quality function deployment) applied to management of automation projects", International Journal of Advanced Manufacturing Technology, Vol. 87 No. 5-8, pp. 2427-2436.

Cristiano, J.J., Liker, J.K. and White, C.C.I. (2001), "Key factors in the successful application of Quality Function Deployment (QFD)”, IEEE Transactions on Engineering Management, Vol. 48 No. 1, pp. 81-95.

Cudney, E., Elrod, C.C. and Uppalanchi, A. (2012), "Analyzing customer requirements for the American Society of Engineering Management using Quality Function Deployment”, Engineering Management Journal, Vol. 24 No. 1, pp. 47-57.

Dehe, B. and Bamford, D. (2017), "Quality Function Deployment and operational design decisions - a healthcare infrastructure development case study", Production Planning \& Control, Taylor \& Francis, pp. 1-16.

Dror, S. (2016), "Identify important factors for service simulation experiments using QFD", Quality and Reliability Engineering International, Vol. 32 No. 6, pp. 2107-2114.

Enríquez, F.T., Osuna, A.J. and Bosch, V.G. (2004), "Prioritizing customer needs at spectator events: Obtaining accuracy at a difficult QFD arena", International Journal of Quality \& Reliability Management, Vol. 21 No. 9, pp. 984-990.

Evans, R.J. and Lindsay, M.W. (2015), An Introduction to Six Sigma \& Process Improvement, Cengage Learning, 
$2^{\text {nd }}$ ed., Stamford, CT.

Fahma, F., Iftadi, I. and Putri, N.A. (2015), “Customer requirement analysis of driver's seat design using Quality Function Deployment (QFD) case study: City Car", Joint International Conference on Electric Vehicular Technology and Industrial, Mechanical, Electrical and Chemical Engineering, pp. 173-177.

Farahmand, N.F. (2009), "Organizational support activities as facilitator in the QFD performance", International Journal of Management and Innovation, Vol. 1 No. 2, pp. 60-71.

Farahmand, N.F. (2011), "Organizational primary activities as facilitator in the quality function deployment (QFD) performance", African Journal of Business Management, Vol. 5 No. 25, pp. 10252-10258.

Fehlmann, T.M. (2005), "The impact of linear algebra on QFD”, International Journal of Quality \& Reliability Management, Vol. 22 No. 1, pp. 83-96.

Franceschini, F. (2002), Advanced Quality Function Deployment, $6{ }^{\mathrm{CRC}}$ Press, Boca Raton, Florida.

Franceschini, F. and Maisano, D. (2015), "Prioritization of QFD customer requirements based on the law of comparative judgments", Quality Engineering, Vol. 27 No. 4, pp. 1-13.

Gandhinathan, R., Raviswaran, N. and Suthakar, M. (2004), "QFD-and VE-enabled target costing: a fuzzy approach", International Journal of Quality \& Reliability Management, Vol. 21 No. 9, p. 1003.

Gerst, R.M. (2004), "QFD in large-scale social system redesign”, International Journal of Quality \& Reliability Management, Vol. 21 No. 9, pp. 959-972.

Ginn, D. and Zairi, M. (2005), "Best practice QFD application : an internal / external benchmarking approach based on Ford Motors' experience”, International Journal of Quality \& Reliability Management, Vol. 22 No. 1, p. 38.

González, M. E. Quesada, G., Picado, F., \& Eckelman, C.A. (2004), "Customer satisfaction using QFD: an ebanking case", Managing Service Quality, Vol. 14 No. 4, pp. 317-330.

Gonzalez, M.E., Quesada, G., Mueller, R. and Mora-Monge, C. a. (2004), "QFD strategy house: an innovative tool for linking marketing and manufacturing strategies", Marketing Intelligence \& Planning, Vol. 22 No. 3, pp. 335348.

Govers C. P.M., (2001), "QFD not just a tool but a way of quality management", International Journal of Production Economics, Vol. 69, pp.151-159.

Gremyr, I. and Raharjo, H. (2013), "Quality function deployment in healthcare: a literature review and case study", International Journal of Health Care Quality Assurance, Vol. 26 No. 2, pp. 135-146.

Griffin, A. (1992), "Evaluating QFD's use in US firms as a process for developing products", Journal of Product Innovation Management, Vol. 9 No. 3, pp. 171-187.

Hadjina, M., Matulja, T. and Rubeša, R. (2015), "Methodology for the ship exploitation feedback inclusion for improving the ship design and production process based on adjusted QFD method", Scientific Journal Of Maritime Research, Vol. 29, pp. 107-114.

Han, S.B., Chen, S.K., Ebrahimpour, M. and Sodhi, M.S. (2001), "A conceptual QFD planning model", International Journal of Quality \& Reliability Management, Vol. 18 No. 8, pp. 796-812.

Hanumaiah, N., Ravi, B. and Mukherjee, N.P. (2006), "Rapid hard tooling process selection using QFD-AHP methodology", Journal of Manufacturing Technology Management, Vol. 17 No. 3, pp. 332-350.

Haron, A., Liyana, F. and Khairudin, M. (2012), "The application of Quality Function Deployment (QFD) In the design phase of Industrialized Building System (IBS) apartment construction project", European International Journal of Science and Technology, Vol. 1 No. 3, pp. 56-66.

Herzwurum G. and Schockert S. (2006), "What are the best practices of QFD?", Proceedings of the $12^{\text {th }}$ International Symposium on Quality Function Deployment. Tokyo.

Ho, W., Dey, P.K. and Lockstrom, M. (2011), "Strategic sourcing: a combined QFD and AHP approach in manufacturing", Supply Chain Management: An International Journal, Vol. 16 No. 6, pp. 446-461.

Ho, Y.C. and Lin, C.H. (2009), "A QFD-, concurrent engineering-, and target costing-based methodology for ODM companies to formulate RFQs", Journal of Manufacturing Technology Management, Vol. 20 No. 8, pp. 11191146.

Huang, G.Q. and Mak, K.L. (2002), "Synchronous quality function deployment (QFD) over world wide web", Computers \& Industrial Engineering, Vol. 42, pp. 425-431. 
Hunt, R.A. and Xavier, F.B. (2003), "The leading edge in strategic QFD”, International Journal of Quality \& Reliability Management, Vol. 20 No. 1, pp. 56-73.

Hussain, M., Tsironis, L. and Ajmal, M.M. (2011), “A QFD strategy for improving customer satisfaction: case study of telecom companies of Pakistan”, Asian Journal on Quality, Vol. 12 No. 3, pp. 282-295.

International Organization for Standardization. (2015). ISO 16355-1:2015 Application of statistical and related methods to new technology and product development process -- Part 1: General principles and perspectives of Quality Function Deployment (QFD). Switzerland

International Organization for Standardization. (2017a). ISO 16355-2:2017 Application of statistical and related methods to new technology and product development process -- Part 2: Non-quantitative approaches for the acquisition of voice of customer and voice of stakeholder. Switzerland

International Organization for Standardization. (2017b). ISO 16355-2:2017 Application of statistical and related methods to new technology and product development process -- Part 4: Analysis of non-quantitative and quantitative Voice of Customer and Voice of Stakeholder. Switzerland

International Organization for Standardization. (2017c). ISO 16355-2:2017 Application of statistical and related methods to new technology and product development process -- Part 5: Solution strategy. Switzerland

International Organization for Standardization. (2017d). ISO 16355-2:2017a Application of statistical and related methods to new technology and product development process -- Part 8: Guidelines for commercialization and life cycle. Switzerland

Jahanzaib, M., Idrees, M., Wasim, A., Hussain, S. and Aziz, H. (2016), "A Framework for implementing Quality Function Deployment (QFD) for utility services", IOSR Journal of Business and Management, Vol. 18 No. 4, pp. 92-99.

Jia, G.Z. and Bai, M. (2011), "An approach for manufacturing strategy development based on fuzzy-QFD", Computers \& Industrial Engineering, Vol. 60 No. 3, pp. 445-454.

$\mathrm{Ju}$, Y. and Sohn, S.Y. (2015), "Patent-based QFD framework development for identification of emerging technologies and related business models: A case of robot technology in Korea", Technological Forecasting and Social Change, Vol. 94, pp. 44-64.

Jui-Chin, J., Ming-Li, S. and Tu, M.H. (2007), "QFDs Evolution in Japan and the West", Quality Progress, Vol. 40 No. 7, p. 30.

Kapucuoglu-Ikiz A. and Ozdagoglu G. (2008), "Customer-driven process improvement in a shipping line company", Transactions of the $20^{\text {th }}$ Symposium on Quality Function Deployment. QFD Institute.

Kaneko N. (2000), "Improving the Nissan Crew with reverse QFD", Transactions of the $12^{\text {th }}$ Symposium on Quality Function Deployment. QFD Institute.

Khorshidi, H.A., Nikfalazar, S. and Gunawan, I. (2016), "Statistical process control application on service quality using SERVQUAL and QFD with a case study in trains' services", The TQM Journal, Vol. 28 No. 2, pp. 195215.

Killen, C.P., Walker, M. and Hunt, R. A. (2005), "Strategic planning using QFD”, International Journal of Quality \& Reliability Management, Vol. 22 No. 1, pp. 17-29.

Kowalska, M., Pazdzior, M. and Krzton-Maziopa, A. (2015), "Implementation of QFD method in quality analysis of confectionery products", Journal of Intelligent Manufacturing, Springer US, pp. 1-9.

Kuo, C.M., Chen, H.T. and Boger, E. (2016), "Implementing city hotel service quality enhancements: Integration of Kano and QFD analytical models", Journal of Hospitality Marketing \& Management, Vol. 25 No. 6, pp. 748770 .

Kwong, C.K., Ye, Y., Chen, Y. and Choy, K.L. (2011), "A novel fuzzy group decision-making approach to prioritizing engineering characteristics in QFD under uncertainties", International Journal of Production Research, Vol. 49 No. 19, pp. 5801-5820.

Lazreg, M. (2011), "QFD-TOPSIS-based model for managing Six Sigma DMAIC process in manufacturing", International Journal of Manufacturing Technology and Management, Vol. 23 No. 3-4, pp. 234-248.

Lee, C.K.M., Ru, C.T.Y., Yeung, C.L., Choy, K.L. and Ip, W.H. (2015), "Analyze the healthcare service requirement using fuzzy QFD", Computers in Industry, Vol. 74, pp. 1-15.

LePrevost, J. and Mazur, G. (2005), "Quality infrastructure improvement: using QFD to manage project management resources", International Journal of Quality \& Reliability Management, Vol. 22 No. 1, p. 10-16. 
Lin, Y. and Pekkarinen, S. (2011), "QFD-based modular logistics service design”, Journal of Business \& Industrial Marketing, Vol. 26 No. 5, pp. 344-356.

Liu, H.T. (2011), "Product design and selection using fuzzy QFD and fuzzy MCDM approaches", Applied Mathematical Modeling, Vol. 35 No. 1, pp. 482-496.

Lo, S.M., Shen, H.P. and Chen, J.C. (2016), "An integrated approach to project management using the Kano model and QFD: an empirical case study", Total Quality Management \& Business Excellence, pp. 1-25.

Marini, C.D., Fatchurrohman, N., Azhari, A. and Suraya, S. (2016), "Product development using QFD, MCDM and the combination of these two methods", IOP Conference Series: Materials Science and Engineering, Vol. 114, IOP, pp. 1-8.

Mazur, G.H. (1993), "QFD for service industries: From voice of customer to task deployment”, Proceedings of Fifth Symposium on Quality Function Deployment, Novi, MI.

Mazur, G.H. (1996), "The application of Quality Function Deployment (QFD) To design a course in Total Quality Management (TQM) at the University of Michigan College Of Engineering", Proceedings of International Conference on Quality-1996 Yokohama, pp. 1-7.

Mazur, G.H. (2014), "Methods and tools of modern QFD”, American Society for Quality webcast, available at: https://secure.asq.org/perl/msg.pl?prvurl=http://asq.org/2014/12/methods-and-tools-of-modern-qfd-webcast-pptslides.pdf.

Michael, E. (1994), “The ABCs of QFD: formalizing the quest for cost-effective customer delight", National Productivity Review, Vol. 13 No. 3, p. 351.

Miguel, P.A.C. (2003), "The state-of-the-art of the Brazilian QFD applications at the top 500 companies", International Journal of Quality \& Reliability Management, Vol. 20 No. 1, pp. 74-89.

Miguel, P.A.C. (2005), "Evidence of QFD best practices for product development: a multiple case study", International Journal of Quality \& Reliability Management, Vol. 22 No. 1, pp. 72-82.

Miguel, P.A.C. (2007), "Innovative new product development: a study of selected QFD case studies", The TQM Magazine, Vol. 19 No. 6, pp. 617-625.

Miguel, P.A.C. (2013), "Benchmarking QFD application for developing packaging products: A comparison between a company in Italy and one in Brazil", Benchmarking: An International Journal, Vol. 20 No. 3, pp. 419-433.

Mitra, A. (2016), Fundamentals of Quality Control and Improvement, $4^{\text {th }}$ ed., John Wiley \& Sons, Inc., Hoboken, New Jersey.

Moskowitz, H. and Kim, K.J. (1997), "QFD optimizer: a novice friendly Quality Function Deployment decision support system for optimizing product designs", Computers \& Industrial Engineering, Vol. 32 No. 3, pp. 641655.

Murali, S., Pugazhendhi, S. and Muralidharan, C. (2016), "Integration of IPA and QFD to assess the service quality and to identify after sales service strategies to improve customer satisfaction - a case study", Production Planning \& Control, Vol. 27 No. 5, pp. 394-407.

Natarajan, R.N., Martz, R.E. and Kurosaka, K. (1999), “Applying QFD to internal service system design”, Quality Progress, Vol. 32 No. 2, pp. 65-70.

National Academy of Engineering and Institute of Medicine (2005), Building a Better Delivery System: A New Engineering/Health Care Partnership, National Academies Press.

Ocampo Jimenez, N.B. and Baeza Serrato, R. (2016), "Effectiveness of QFD in a municipal administration process", Business Process Management Journal, Vol. 22 No. 5, pp. 979-992.

Okan D., Huang, S.T., Bulut, E. and Yoshida, S. (2013), "Multi-layer quality function deployment ( QFD ) approach for improving the compromised quality satisfaction under the agency problem : A 3D QFD design for the asset selection problem in the shipping industry", Quality and Quantity, Vol. 47, pp. 2259-2280.

Okur, A., Nasibov, E.N., Kiliç, M. and Yavuz, M. (2009), "Using OWA aggregation technique in QFD: A case study in education in a textile engineering department", Quality and Quantity, Vol. 43 No. 6, pp. 999-1009.

Parkin, N., Linsley, M.J., Chan, J.F.L. and Stewardson, D.J. (2002), "The introduction of QFD in a UK original equipment manufacturer”, Managerial Auditing Journal, Vol. 17 No. 1/2, pp. 43-54.

Paryani, K., Masaudi, A. and Cudney, E. a. (2010), "QFD application in the hospitality industry: a hotel case study", The Quality Management Journal, Vol. 17 No. 1, pp. 7-28. 
Pasawang, T., Chatchanayuenyong, T. and Sa-Ngiamvibool, W. (2015) 'QFD-based conceptual design of an autonomous underwater robot', Journal of Science \& Technology, Vol 37, No. 6, pp.659-668.

Pitman, G., Motwani, J., Kumar, A. and Cheng, C.H. (1995), "QFD application in an educational setting: A pilot field study”, International Journal of Quality \& Reliability Management, Vol. 13 No. 4, pp. 99-108.

Politis, J.D. (2003), "QFD: the role of various leadership styles", Leadership \& Organization Development Journal, Vol. 24 No. 4, pp. 181-192.

Politis, J.D. (2005), "QFD, organizational creativity and productivity", International Journal of Quality \& Reliability Management, Vol. 22 No. 1, pp. 59-71.

Prasad, B. (1998), "Review of QFD and related deployment techniques", Journal of Manufacturing Systems, Vol. 17 No. 3, pp. 221-234.

Rahman, A. and Baksh M. (2003), "Application of quality function deployment ( QFD ) method for pultrusion machine design planning”, Industrial Management \& Data Systems, Vol. 103 No. 5/6, pp. 373-387.

Rahman, Z. and Qureshi, M.N. (2008), "Developing new services using fuzzy QFD: a LIFENET case study.", International Journal of Health Care Quality Assurance, Vol. 21 No. 7, pp. 638-658.

Ramasamy, N.R. and Selladurai, V. (2004), "Fuzzy logic approach to prioritize engineering characteristics in quality function deployment (FL-QFD)", International Journal of Quality \& Reliability Management, Vol. 21 No. 9, p. 1012.

Rattawut, V. (2015), "Integration of Fuzzy-QFD and AHP base on A Fuzzy scale for mini-CNC Milling Machine Retrofit”, Industrial Control Systems Security (WCICSS), 2015 World Congress on, pp. 89-94.

Sayadi, S., Erraach, Y. and Parra-López, C. (2017), “Translating consumer's olive-oil quality-attribute requirements into optimal olive-growing practices", British Food Journal, Vol. 119 No. 1, pp. 190-214.

Schilloa, R.S., Isabelleb, D.A. and Shakibac, A. (2017), "Linking advanced biofuels policies with stakeholder interests: A method building on Quality Function Deployment", Energy Policy, Vol. 100 No. January, pp. 126137.

Sharma, J.R. and Rawani, A.M. (2007), "Ranking customer requirements in QFD by factoring in their interrelationship values", The Quality Management Journal, Vol. 14 No. 4, pp. 53-60.

Sharma, J.R. and Rawani, A.M. (2009), "Linking company with customers and competitors : a comprehensive QFD model and its post-matrix analysis", International Journal of Modeling and Simulation, Vol. 29 No. 2, pp. 191198.

Shin, J.S. and Kim, K.J. (2000), "Complexity reduction of a design problem in QFD using decomposition", Journal of Intelligent Manufacturing, Vol. 11 No. 4, pp. 339-354.

Shiu, M.L., Jiang, J.C. and Tu, M.H. (2007), "Reconstruct QFD for integrated product and process development management", The TQM Magazine, Vol. 19 No. 5, pp. 403-418.

Silva, F.L.R. da, Cavalca, K.L. and Dedini, F.G. (2004), "Combined application of QFD and VA tools in the product design process", International Journal of Quality \& Reliability Management, Vol. 21 No. 2, pp. 231-252.

Sireli, Y., Kauffmann, P. and Ozan, E. (2007), "Integration of Kano's model into QFD for multiple product design”, IEEE Transactions on Engineering Management, Vol. 54 No. 2, pp. 380-390.

Summers, C.A. (2005), Using Quality Function Deployment (QFD) To Design Quality Assurance Programs For Retail/Wholesale Operations, California State University Dominguez Hills.

Suryaningrat, I.B. (2016), "Implementation of QFD in food supply chain management : a case of processed cassava product in Indonesia", International Journal on Advanced Science Engineering Information Technology, Vol. 6 No. 3, pp. 302-305.

Tague, N.R. (2005), "2.1 The Evolution of Quality", Quality Toolbox, $2^{\text {nd }}$ ed., American Society for Quality (ASQ), pp. 13-34.

Terziovski M. and Sohal A.M. (2000), "The adoption of continuous improvement and innovation strategies in Australian manufacturing firms", Technovation, Vol 20, pp. 539-550.

Tidwell, A. and Sutterfield, J.S. (2012), "Supplier selection using QFD: a consumer products case study", International Journal of Quality \& Reliability Management, Vol. 29 No. 3, pp. 284-294.

Tontini, G. (2007), "Integrating the Kano Model and QFD for designing new products", Total Quality Management \& Business Excellence, Vol. 18 No. 6, pp. 599-612. 
Tottie, M. and Lager, T. (1995), "QFD-linking the customer to the product development process as a part of the TQM concept", R\&D Management, Vol. 25 No. 3, pp. 257-267.

Tsai, Y.C., Chin, K.S. and Yang, J.B. (2002), "A hybrid QFD framework for new product development”, Asian Journal on Quality, Vol. 3 No. 2, pp. 138-158.

Tseng, C., and Torng, C. (2014), "An integrating framework for prioritizing tasks in designing management system improvement projects”, European Journal of Industrial Engineering, Vol. 8 No. 4, pp. 457-477.

Vezzetti, E., Marcolin, F. and Guerra, A.L. (2016), “QFD 3D: a new C-shaped matrix diagram quality approach”, International Journal of Quality \& Reliability Management, Vol. 33 No. 2, pp. 178-196.

Vinodh, S. and Chintha, S.K. (2011a), "Application of fuzzy QFD for enabling leanness in a manufacturing organization", International Journal of Production Research, Vol. 49 No. 6, pp. 343-357.

Vinodh, S. and Chintha, S.K. (2011b), "Application of fuzzy QFD for enabling sustainability", International Journal of Sustainable Engineering, Vol. 4 No. 4, pp. 343-357.

Wang, H., Chen, G., Lin, Z. and Wang, H. (2005), "Algorithm of integrating QFD and TRIZ for the innovative design process", International Journal of Computer Applications in Technology, Vol. 23 No. 1, pp. 41-52.

Wolniak, E.R. and Sędek, A. (2009), "Using QFD method for the ecological designing of products and services", Quality and Quantity, Vol. 43 No. 4, pp. 695-701.

Yazdani, M., Hashemkhani Zolfani, S. and Zavadskas, E.K. (2016), "New integration of MCDM methods and QFD in the selection of green suppliers", Journal of Business Economics and Management, pp. 1-17.

Yousef, N. and Mehrabian, A. (2016), "Using QFD to develop a curriculum that addresses skills gap with Industry", Proceedings of the 2016 Industrial and Systems Engineering Research Conference.

Yu, C., Chen, C.-K., Chen, W. and Chang, H.-C. (2012), "Developing a revised QFD technique to meet the needs of multiple-customer groups: a case of public policy analysis", Total Quality Management \& Business Excellence, Vol. 23 No. 12, pp. 1-19.

Zubek M, and Nibley F. (1994), “Aligning Process Improvement with the Voice of the Customer." Transactions of the $6^{\text {th }}$ Symposium on QFD. QFD Institute. 
Table 1. QFD Implementation Areas

\begin{tabular}{|c|c|c|c|c|c|}
\hline \multirow{2}{*}{ Industry/ Setting } & \multirow{2}{*}{ Source } & \multicolumn{2}{|c|}{ Context } & \multicolumn{2}{|c|}{ Application } \\
\hline & & M & $\mathrm{S}$ & DD & I \\
\hline \multirow{4}{*}{ Automotive } & $\begin{array}{l}\text { Gandhinathan et al., 2004; Wang et al., 2005; Chen \& Ngai, 2008; Cherif et } \\
\text { al., 2009; \& Bhattacharyya \& Chaudhuri, 2009; Fahma et al., 2015; Cordeiro } \\
\text { et al., 2016; }\end{array}$ & $\mathrm{X}$ & & $\mathrm{X}$ & \\
\hline & Miguel, 2005; & $\mathrm{X}$ & & & \\
\hline & Ho et al., 2011; & & $\mathrm{X}$ & $\mathrm{X}$ & \\
\hline & Al-Mashari et al., 2005; & & & & \\
\hline \multirow{2}{*}{ Banking } & Andronikidis et al., 2009; & & $\mathrm{X}$ & $\mathrm{X}$ & $\mathrm{X}$ \\
\hline & Gonzalez et al., 2004; & & $\mathrm{X}$ & & $\mathrm{X}$ \\
\hline \multirow{2}{*}{ Communication } & Fehlmann, 2005; & & $\mathrm{X}$ & & \\
\hline & Hussain et al., 2011; & & $\mathrm{X}$ & & $\mathrm{X}$ \\
\hline \multirow{2}{*}{ Construction } & Liu, 2011; & $\mathrm{X}$ & & $\mathrm{X}$ & \\
\hline & Armacost et al., 1994; Shin \& Kim, 2000; Haron et al., 2012; & & $\mathrm{X}$ & $\mathrm{X}$ & \\
\hline \multirow[t]{2}{*}{ Education } & $\begin{array}{l}\text { Mazur, 1996; Natarajan et al., 1999; Chan \& Mazur, 2010; Yousef \& } \\
\text { Mehrabian, 2016; }\end{array}$ & & $\mathrm{X}$ & $\mathrm{X}$ & \\
\hline & Pitman et al., 1995; Okur et al., 2009; Cudney et al., 2012; & & $\mathrm{X}$ & & $\mathrm{X}$ \\
\hline \multirow{3}{*}{$\begin{array}{l}\text { Electronics and } \\
\text { Robotics }\end{array}$} & Vinodh \& Chintha, 2011b; Ju \& Sohn, 2015; & $\mathrm{X}$ & & $\mathrm{X}$ & $\mathrm{X}$ \\
\hline & Chen \& Wu, 2007; & $\mathrm{X}$ & & & $\mathrm{X}$ \\
\hline & Jia \& Bai, 2011; Pasawang et al., 2015; & & $\mathrm{X}$ & $\mathrm{X}$ & \\
\hline Energy & Schilloa et al., 2017; Jahanzaib et al., 2016; & & $\mathrm{X}$ & $\mathrm{X}$ & \\
\hline \multirow{3}{*}{$\begin{array}{l}\text { Environment and } \\
\text { Safety }\end{array}$} & Batson \& Moynihan, 2004; Wolniak \& Sędek, 2009; Tseng \& Torng, 2014; & & $\mathrm{X}$ & $\mathrm{X}$ & \\
\hline & Vinodh \& Chintha, 2011a; & $\mathrm{X}$ & & & $\mathrm{X}$ \\
\hline & Yazdani et al., 2016; & & $\mathrm{X}$ & & \\
\hline Facility Location & Chadawada et al., 2015; & & $\mathrm{X}$ & $\mathrm{X}$ & \\
\hline \multirow{3}{*}{ Food and Sanitary } & Miguel, 2005; & $\mathrm{X}$ & & & \\
\hline & Tontini, 2007; Kowalska \& Pazdzior, 2015; & $\mathrm{X}$ & & $\mathrm{X}$ & \\
\hline & Suryaningrat, 2016; Sayadi et al., 2017; & & $\mathrm{X}$ & $\mathrm{X}$ & \\
\hline \multirow{4}{*}{ Healthcare } & $\begin{array}{l}\text { Benitez et al., 2007; Rahman \& Qureshi, 2008; Gremyr \& Raharjo, 2013; } \\
\text { Dehe \& Bamford, 2017; }\end{array}$ & & $\mathrm{X}$ & $\mathrm{X}$ & \\
\hline & Sharma and Rawani, 2007; Sharma \& Rawani, 2009; & $\mathrm{X}$ & & $\mathrm{X}$ & \\
\hline & Azadi \& Farzipoor Saen, 2013; & & $\mathrm{X}$ & & \\
\hline & Lee et al., 2015; Buttigieg et al., 2016; & & $\mathrm{X}$ & & $\mathrm{X}$ \\
\hline \multirow{2}{*}{ Hospitality } & Enriquez et al., 2004; & & $\mathrm{X}$ & & \\
\hline & Paryani et al., 2010; Kuo et al., 2016; & & $\mathrm{X}$ & & $\mathrm{X}$ \\
\hline \multirow{3}{*}{$\begin{array}{l}\text { Metal and } \\
\text { Machinery }\end{array}$} & $\begin{array}{l}\text { Tottie \& Lager, 1995; Han et al., 2001; Rahman \& Baksh, 2003; Ramasamy } \\
\text { \& Selladurai, 2004; Hanumaiah et al., 2006; Kwong et al., 2011; Rattawut, } \\
\text { 2015; }\end{array}$ & $\mathrm{X}$ & & $\mathrm{X}$ & \\
\hline & Miguel, 2005; & $\mathrm{X}$ & & & \\
\hline & Alsyouf et al., 2011; & & $\mathrm{X}$ & & $\mathrm{X}$ \\
\hline \multirow{2}{*}{ Packaging } & Chen \& Ko, 2009; Miguel, 2013; & $\mathrm{X}$ & & $\mathrm{X}$ & \\
\hline & Tidwell and Sutterfield, 2012; & & $\mathrm{X}$ & & \\
\hline \multirow{3}{*}{$\begin{array}{l}\text { Project } \\
\text { Management and } \\
\text { Planning }\end{array}$} & Ahmed et al., 2003; LePrevost \& Mazur 2005; Lin \& Pekkarinen, 2011; & & $\mathrm{X}$ & $\mathrm{X}$ & \\
\hline & Killen et al., 2005; & & $\mathrm{X}$ & & \\
\hline & Lo et al., 2016; & & $\mathrm{X}$ & & $\mathrm{X}$ \\
\hline Sales and Marketing & Summers, 2005; Yu et al., 2012; Dror, 2016; Murali et al., 2016; & & $\mathrm{X}$ & $\mathrm{X}$ & \\
\hline \multirow{3}{*}{$\begin{array}{l}\text { Social } \\
\text { Administration }\end{array}$} & Gerst, 2004; & & $\mathrm{X}$ & $\mathrm{X}$ & \\
\hline & Ocampo Jimenez \& Baeza Serrato, 2016; & & $\mathrm{X}$ & & $\mathrm{X}$ \\
\hline & Vezzetti et al., 2016; & & $\mathrm{X}$ & & \\
\hline Stationery & Balthazard \& Gargeya, 1995; Tsai et al., 2002; & $\mathrm{X}$ & & $\mathrm{X}$ & \\
\hline \multirow{3}{*}{$\begin{array}{l}\text { Transportation } \\
\text { vehicle and system }\end{array}$} & Silva et al., 2004; Hadjina et al., 2015; Franceschini \& Maisano, 2015; & $\mathrm{X}$ & & $\mathrm{X}$ & \\
\hline & Sireli et al., 2007; Khorshidi et al., 2016; & & $\mathrm{X}$ & $\mathrm{X}$ & \\
\hline & Okan et al., 2013; & & $\mathrm{X}$ & & $\mathrm{X}$ \\
\hline \multirow{2}{*}{ Textile } & Bergquist \& Abeysekera, 1996; & $\mathrm{X}$ & & $\mathrm{X}$ & \\
\hline & Camgöz-Akdağ et al., 2016; & & $\mathrm{X}$ & & $\mathrm{X}$ \\
\hline
\end{tabular}

DD: Design and Development; I: Improvement; M: Manufacturing; S: Service 
Table 2. Symbols used in the roof of House of Quality

\begin{tabular}{|c|l|}
\hline Symbol & Relation \\
\hline$\bullet$ & Strong positive correlation \\
\hline$\circ$ & Positive correlation \\
\hline$\aleph$ & Negative correlation \\
\hline \multirow{*}{*}{} & Strong negative correlation \\
\hline
\end{tabular}

Table 3. Symbols used in the relationship matrix

\begin{tabular}{|c|l|l|}
\hline Symbol & Relationship & Score \\
\hline$\bullet$ & Strong relationship & 9 \\
\hline$\circ$ & Medium relationship & 3 \\
\hline $\boldsymbol{\Delta}$ & Weak relationship & 1 \\
\hline
\end{tabular}

Table 4. List of issues generated by the QFD team

\begin{tabular}{|l|l|l|}
\hline Category & Issues & Attribute \\
\hline \multirow{4}{*}{ Product } & \multirow{4}{*}{ Appearance } & Color Variation \\
\cline { 3 - 3 } & & Shiny-surface \\
\cline { 3 - 3 } & \multirow{4}{*}{ Structure } & Durable Packaging \\
\hline \multirow{4}{*}{ Service } & & Straightness \\
\cline { 3 - 3 } & \multirow{3}{*}{ Sales } & Accurate Dimension \\
\cline { 3 - 3 } & & High Resistance \\
\hline & & Price \\
\cline { 3 - 3 } & & After Sales Services \\
\hline
\end{tabular}

Table 5. Wholesaler evaluation of complaints

\begin{tabular}{|l|l|l|l|l|l|}
\hline \multirow{2}{*}{$\begin{array}{l}\text { Item } \\
\#\end{array}$} & \multirow{2}{*}{ Complaint Type } & \multicolumn{2}{|l|}{ Occurrence (Weight) } & \multirow{2}{*}{$\begin{array}{l}\text { Frequency } \\
\text { (F) }\end{array}$} \\
\cline { 3 - 5 } & & $\begin{array}{l}\text { Frequently } \\
(2)\end{array}$ & $\begin{array}{l}\text { Occasionally } \\
(1)\end{array}$ & $\begin{array}{l}\text { Rarely } \\
(0)\end{array}$ & \\
\hline 1 & Color Variation & 54 & 21 & 5 & 43 \\
\hline 2 & Price & 43 & 26 & 11 & 37 \\
\hline 3 & Accurate Dimension & 40 & 31 & 9 & 37 \\
\hline 4 & Inventory Availability & 37 & 31 & 12 & 35 \\
\hline 5 & Straightness & 28 & 23 & 29 & 26 \\
\hline 6 & Shiny-surface & 26 & 26 & 28 & 26 \\
\hline 7 & High Resistance & 22 & 31 & 27 & 25 \\
\hline 8 & Durable Packaging & 10 & 34 & 36 & 18 \\
\hline 9 & After Sales Services & 0 & 36 & 44 & 12 \\
\hline
\end{tabular}


Table 6. Customer complaints prior to QFD implementation

\begin{tabular}{|l|l|l|}
\hline Item $\#$ & Complaint Type & Frequency \\
\hline 1 & Color Variation & 5 \\
\hline 3 & Accurate Dimension & 4 \\
\hline 4 & Inventory Availability & 6 \\
\hline 5 & Straightness & 7 \\
\hline 7 & High Resistance & 6 \\
\hline 9 & After Sales Services & 4 \\
\hline 10 & Other & 22 \\
\hline
\end{tabular}

Table 7. Customer requirements and their degrees of importance

\begin{tabular}{|c|l|c|c|c|c|c|c|}
\hline \multirow{2}{*}{ Item \# } & \multirow{2}{*}{$\begin{array}{l}\text { Customer } \\
\text { Requirement }\end{array}$} & \multicolumn{2}{|c|}{$\begin{array}{c}\text { Interviews } \\
\text { (Weight=2) }\end{array}$} & \multicolumn{2}{c|}{$\begin{array}{c}\text { Complaint History } \\
\text { (Weight=5) }\end{array}$} & \multicolumn{2}{c|}{ Degree of importance } \\
\cline { 3 - 8 } & Frequency & $\begin{array}{c}\text { Relative } \\
\text { Rank }\end{array}$ & Frequency & $\begin{array}{c}\text { Relative } \\
\text { Rank }\end{array}$ & $\begin{array}{c}\text { Cumulative } \\
\text { Rank }\end{array}$ & $\begin{array}{c}(1-9) \\
\text { Scale }\end{array}$ \\
\hline 1 & Color Variation & 43 & 0.17 & 5 & 0.16 & 0.16 & 7.7 \\
\hline 2 & Price & 37 & 0.14 & 0 & 0.00 & 0.04 & 2.0 \\
\hline 3 & $\begin{array}{l}\text { Accurate } \\
\text { Dimension }\end{array}$ & 37 & 0.14 & 4 & 0.13 & 0.13 & 6.3 \\
\hline 4 & $\begin{array}{l}\text { Inventory } \\
\text { Availability }\end{array}$ & 35 & 0.13 & 6 & 0.19 & 0.17 & 8.4 \\
\hline 5 & Straightness & 26 & 0.10 & 7 & 0.22 & 0.19 & 9.0 \\
\hline 6 & Shiny-surface & 26 & 0.10 & 0 & 0.00 & 0.03 & 1.4 \\
\hline 7 & High Resistance & 25 & 0.10 & 6 & 0.19 & 0.16 & 7.8 \\
\hline 8 & Durable Packaging & 18 & 0.07 & 0 & 0.00 & 0.02 & 1.0 \\
\hline 9 & $\begin{array}{l}\text { After Sales } \\
\text { Services }\end{array}$ & 12 & 0.05 & 4 & 0.13 & 0.10 & 5.0 \\
\hline & & 260 & & 32 & & & \\
\hline
\end{tabular}

